\title{
OXYTOCIC ACTIVITY IN UNEXTRACTED BLOOD PLASMA DURING CALVING
}

\author{
C. G. VAN DONGEN* AND R. L. HAYS \\ Department of Dairy Science, University of Illinois, Urbana, Illinois, U.S.A.
}

(Received 15th March 1965, revised 8th November 1965)

Summary. The oxytocic activity of unextracted blood plasma of calving cows increased from undetectable levels $\left(<1 \times 10^{-10}\right.$ i.u. $\left./ \mathrm{ml}\right)$ up to approximately $1 \times 10^{-4} \mathrm{i}$.u. $/ \mathrm{ml}$ within a few minutes before the time of expulsion of the calf, followed by a rapid decrease after parturition. The results indicate that the initiation of calving is not dependent on the oxytocic activity in the blood, but that blood oxytocic activity plays a role in the expulsion of the calf. These findings support the view that oxytocin has a physiological role in labour.

\section{INTRODUCTION}

Published evidence supports the hypothesis that various neural stimuli from external and internal receptors act through the hypothalamus on the posterior pituitary gland causing the release of the hormone oxytocin into the general circulation. This series of events has been postulated to be involved in the phenomenon of labour. Strong direct experimental evidence, supporting a physiological role for oxytocin during labour, could be provided if reliable quantitative changes in oxytocic activity of blood plasma could be demonstrated during labour.

There are reports on the oxytocic activity in the blood during labour: Bell \& Morris (1934) and Bell \& Robson (1935) in women, cows and rabbits; Fitzpatrick (196la, b) in women and sheep; Fitzpatrick \& Walmsley (1962) in cows; Hawker \& Robertson (1957) in women; and Knaggs (1963) in goats. The published results have been obtained with bio-assays of relatively low sensitivities. The adequate determination of oxytocic activity in the blood plasma by these methods required extraction and concentration procedures.

The purpose of this study was to obtain quantitative data on the oxytocic activity in unextracted blood plasma throughout calving, using a sensitive quantitative assay reported by van Dongen \& Hays (1964, 1966).

\section{MATERIALS AND METHODS}

The external jugular vein of cows was cannulated before calving. Throughout calving an intermittent series of blood samples was taken from the unoccluded

* Present address: Department of Pharmacology, Harvard Medical School, Boston, Massachusetts, U.S.A. 
vein. Each $5 \mathrm{ml}$ sample of blood was taken using a $10 \mathrm{ml}$ polyethylene syringe containing $0.1 \mathrm{ml}$ heparin solution (concentration $1 \mathrm{mg}$ heparin-sodium $/ \mathrm{ml}$ isotonic saline). The time required to collect a blood sample was about $10 \mathrm{sec}$. Within $60 \mathrm{sec}$ after collection the blood sample was cooled to a temperature below $10^{\circ} \mathrm{C}$, placed into a pre-cooled polyethylene tube and then maintained at a temperature of $0^{\circ} \mathrm{C}$. Within a period of $2 \mathrm{hr}$ after blood collection, the blood samples were centrifuged at $0^{\circ} \mathrm{C}$. The blood plasma was then stored in $1 \mathrm{ml}$ glass ampoules at $-18^{\circ} \mathrm{C}$ until the oxytocic activity was assayed. It was assumed that the kinin formation in glass ampoules is negligible at low storage temperatures.

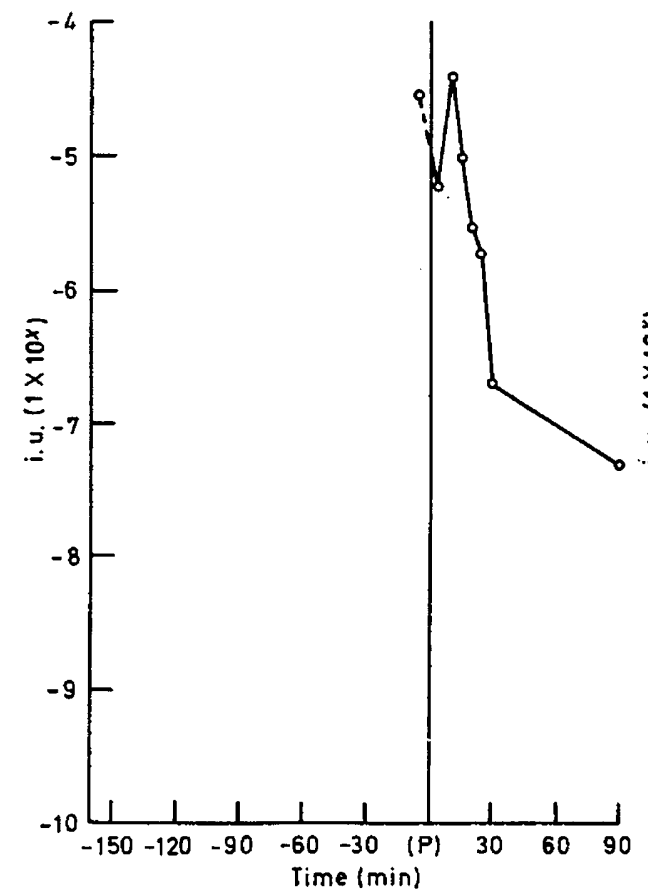

TeXT-FIG. 1

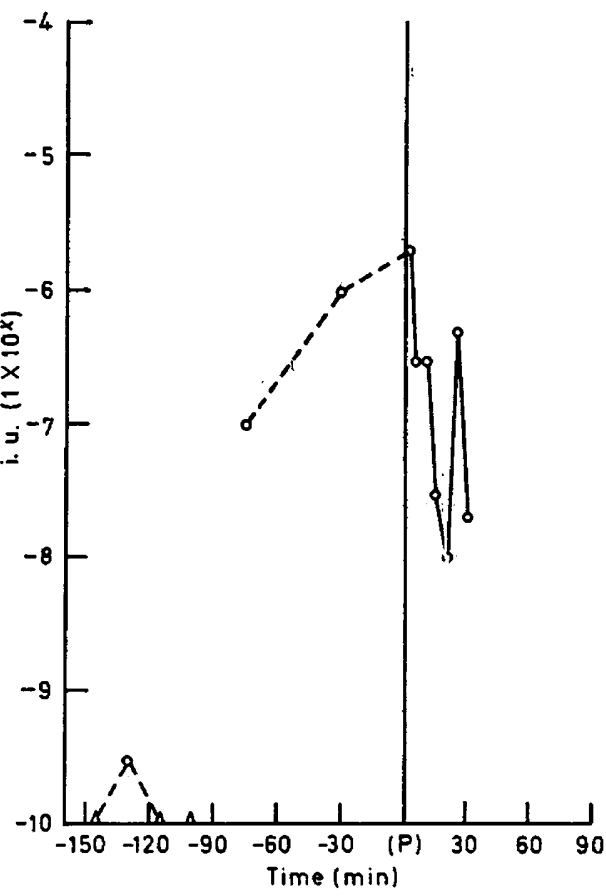

TEXT-FIG. 2

Text-FIG. 1. The oxytocic activity in the jugular blood plasma of cow No. 1 shown in relation to the time of normal parturition.

TexT-Fig. 2. The oxytocic activity in the jugular blood plasma of cow No. 2 shown in relation to the time of normal parturition. $\Delta$, Below quantitative assay threshold.

The oxytocic activity in unextracted blood plasma was determined by a method developed by van Dongen \& Hays (1964). This method makes use of the time required to initiate milk ejection using approximately $(2 \mathrm{~mm})^{3}$ pieces of rat mammary tissue in a drop of blood plasma or solution containing oxytocin. There is an inverse linear relationship between the log of the time required and the $\log$ oxytocin concentration. The oxytocic activity in the blood plasma samples was determined by comparing the time the plasma required to initiate milk ejection with the times a series of standard solutions of oxytocin required using similar pieces of tissue from the same gland. Because 
the precision of the method is still low $(\lambda=1.02)$, the mean of five determinations was used to estimate the oxytocic activity in each sample of blood plasma.

The results were analysed according to established statistical procedures (Snedecor, 1946).

\section{RESULTS}

Parturition, here, refers to the moment the shoulders of the calf pass through the vulva. The time the blood samples were collected is in reference to the moment of parturition. The estimates of plasma oxytocic activity during four calvings are shown in Table 1 and Text-figs. 1 to 4 . Cow No. 4 gave birth to twin calves. The time interval over which blood samples were collected ranged

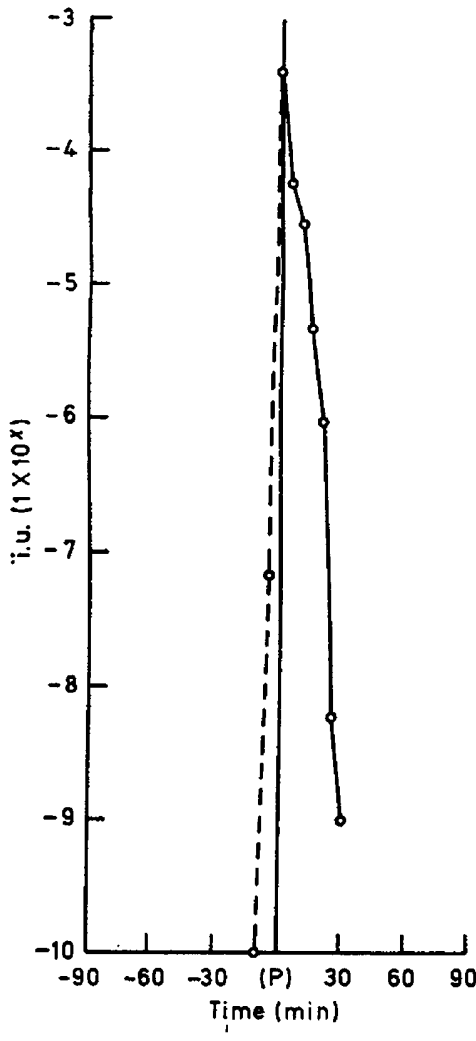

TEXT-FIG. 3

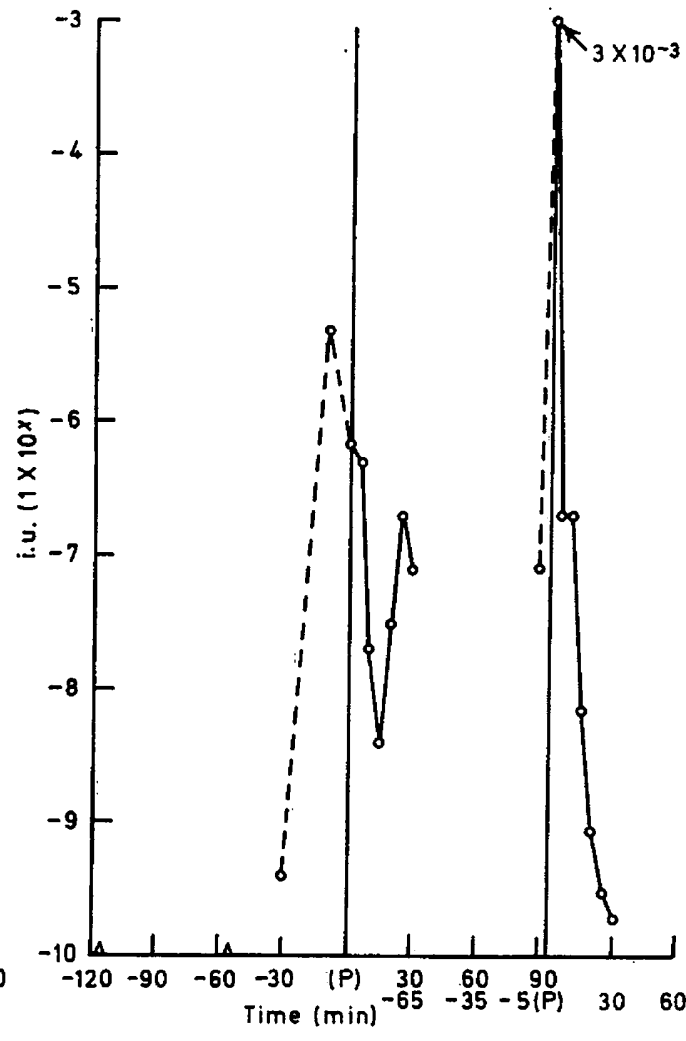

TEXT-FIG. 4

Text-Fig. 3. The oxytocic activity in the jugular blood plasma of cow No. 3 shown in relation to the time of normal parturition.

Text-Fig. 4. The oxytocic activity in the jugular blood plasma of cow No. 4 (this cow gave birth to twins) shown in relation to the time of normal parturition. $\Delta$, Below quantitative assay threshold.

from 0 to $120 \mathrm{~min}$ before and for $30 \mathrm{~min}$ after parturition. The data indicate that the oxytocic activities varied greatly between and within cows, with activities ranging from below the quantitative assay threshold level $\left(1 \times 10^{-10}\right.$ i.u./ml) up to as high as $3 \times 10^{-3}$ i.u./ml. The highest oxytocic activity was 

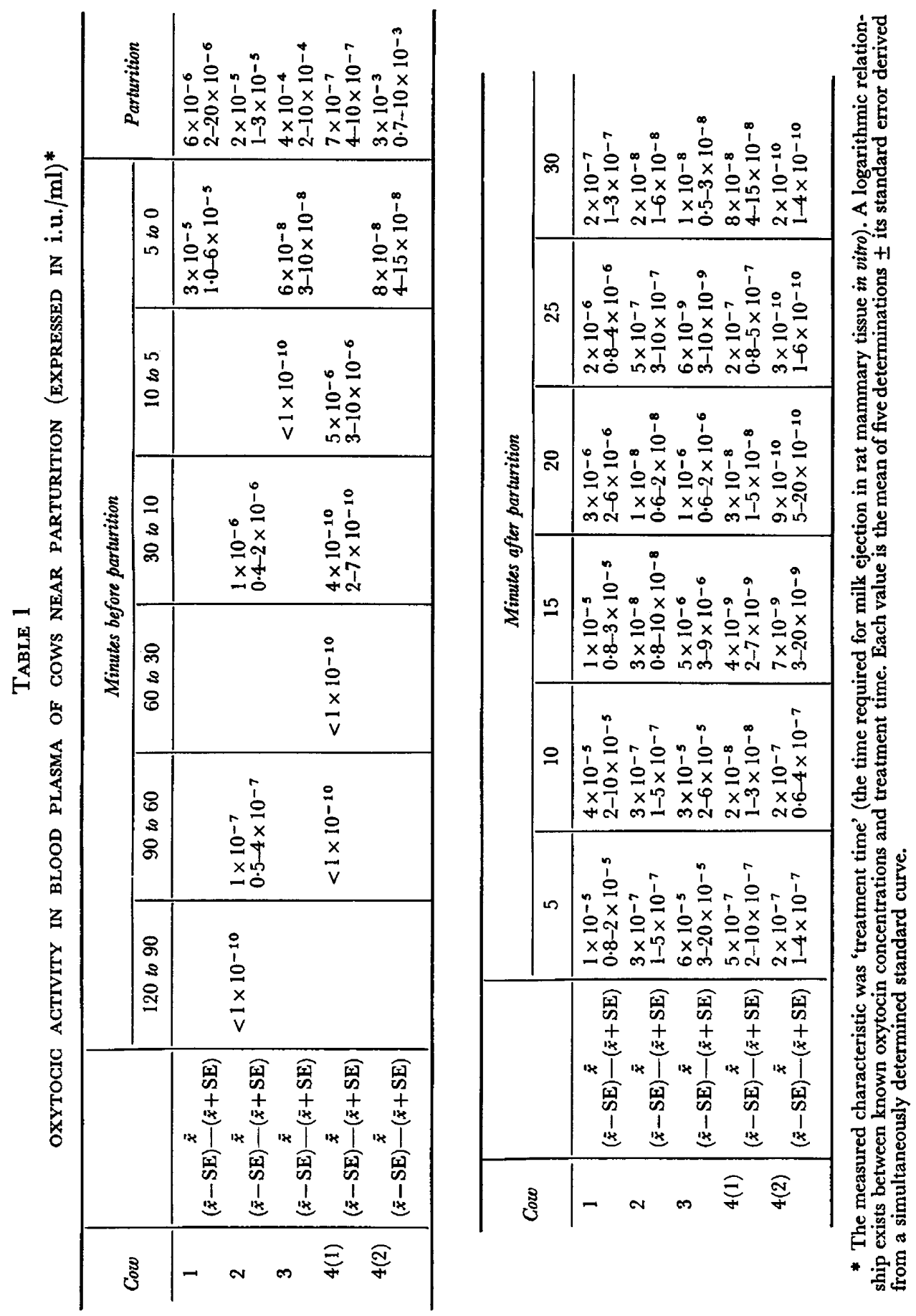
found at the time of parturition in cows Nos. 2, 3 and 4 (calf No. 2), whereas the highest oxytocic activity in cows Nos. 1 and 4 (calf No. 1) was noted within 10 min of parturition. The maximal observed oxytocic activities of the individual cows ranged from $5 \times 10^{-6}$ to $3 \times 10^{-3} \mathrm{i}$.u. $/ \mathrm{ml}$.

The data further indicate that the oxytocic activity in the blood was near or below the measurable limit until shortly before parturition and rose sharply to a maximal level at about parturition. After parturition the oxytocic activity dropped rapidly in cows Nos. 3 and 4 (calf No. 2). An initial drop followed by variable oxytocic activities after parturition were noted in cows Nos. 2 and 4 (calf No. 1).

\section{DISCUSSION}

More accurate studies on the participation of oxytocin in reproductive physiology became possible only in recent years (around 1960) because of the development of improved extraction procedures for oxytocin in blood plasma and increased sensitivity of assays. The results reported here were obtained with unextracted blood plasma and are not confounded with extraction procedures. Moreover, the absence of oxytocic activity in some pre-partum blood samples suggests that the various steps taken to prepare samples for assay did not cause the release of substances with milk-ejecting activity in the blood or blood plasma in vitro. Thus, the measured oxytocic activity is probably indicative of the in-vivo situation of the blood plasma during calving.

In the present study no oxytocic activity could be detected until shortly before parturition. This is in agreement with the findings of Knaggs (1963) in goats, but contrary to findings in cows and women (Fitzpatrick, 1961a; Fitzpatrick \& Walmsley, 1962). The oxytocic activity then rose sharply from below quantitative assay threshold levels $\left(<1 \times 10^{-10}\right.$ i.u. $\left./ \mathrm{ml}\right)$ to $1 \times 10^{-5}$ i.u. of oxytocin $/ \mathrm{ml}$ or higher, which is a much larger increase than the increase in activity observed by Fitzpatrick (1961a) in extracted blood plasma of women. The maximum oxytocic activity of $3 \times 10^{-3}$ i.u. $/ \mathrm{ml}$ and its rapid decrease after parturition, confirms earlier published findings (Fitzpatrick, 1961a; Knaggs, 1963). By $30 \mathrm{~min}$ after parturition the oxytocic activity was usually between $1 \times 10^{-8}$ and $1 \times 10^{-10}$ i.u./ml. The oxytocic activity of the blood plasma of cow No. 2 was variable after parturition. These changes in activity could not be associated with any observable physiological occurrences in or treatment to the animal. The variable oxytocic activity levels after the first calving of cow No. 4 were probably due to the presence of the second calf. The apparent failure of the oxytocic activity level to return to preparturition levels and its irregularity suggest the release of oxytocic activity between the birth of the first and second calf. This may also have contributed to the unusually high level of oxytocic activity in blood plasma at the second parturition. Folley \& Knaggs (1964) reported a similar result with twins.

Studies aimed at chemical identification of the observed oxytocic activity in unextracted blood plasma have not been performed. The high sensitivity of our assay system to oxytocin and biological and chromatographic experimental evidence from other investigators (Fitzpatrick, 196la; Fitzpatrick \& Walmsley, 
1962; Knaggs, 1963) suggest that the observed oxytocic activity might be due to oxytocin. There is, however, the possibility that substances with milkejecting activity other than oxytocin were released into the blood during parturition.

Experimental evidence from the literature suggests an explanation for the sharp rise of oxytocic activity in blood plasma shortly before parturition. Ferguson (1941) observed that mechanical dilatation of the uterus or cervix of the post-parturient rabbit evoked an increase in uterine activity resembling that produced by injection of oxytocic extract. This response was abolished by electrolytic destruction of the pituitary stalk. Andersson (1951) showed that stimulation of the portio uteri of goats produced an ejection of milk and that this effect was of the same intensity in the intact as in the denervated half of the udder. These findings indicate the involvement of a hormonal factor, released from the pituitary gland. Hays \& VanDemark (1953) showed that blood taken from cows before massage of the vulva and cervix had no effect, but blood taken after stimulation caused contractions of excised, perfused cow uteri similar to those caused by oxytocin, whereas Debackere \& Peeters (1960) found the vaginal distension to be much more effective in causing milk ejection than cervical stimulation.

The rapid decrease of oxytocic activity after parturition might be explained by the absence of additional oxytocin release along with possible enzymatic breakdown of oxytocin by blood and organs of parturient cows. In this connection, the presence of an enzyme, oxytocinase, observed in the blood plasma of pregnant and parturient women might be of importance (Mendez-Bauer, Carballo, Cabot, Negreiros de Paiva \& Gonzales-Panizza, 1961; Tuppy, 1961). Also, inactivation of oxytocin was shown to occur in homogenates of uteri and other tissues from normal and pregnant rats (Sawyer, 1954).

The experimental evidence reported here shows that during the initial stages of labour oxytocic activity in the blood plasma is very low or absent, but that high oxytocic activity is found near the time of the actual expulsion of the calf. This evidence supports the contention that oxytocin plays a physiological role in labour.

\section{REFERENCES}

ANdersson, B. (1951) Some observations on the neuro-hormonal regulation of milk ejection. Acta physiol. scand. $23,1$.

BELL, G. H. \& Morris, S. (1934) The oxytocic property of the blood of the cow. F. Physiol., Lond. 81, 63.

BeLl, G. H. \& Rosson, J. M. (1935) Oxytocic properties of blood extracts and their physiological significance. F. Physiol., Lond. 84, 351.

Debackere, M. \& Peeters, G. (1960) The influence of vaginal distension on milk ejection and diuresis in the lactating cow. Archs int. Pharmacodyn. Ther. 123, 462.

Ferguson, J. K. W. (1941) A study of the motility of the intact uterus at term. Surgery Gynec. Obstet. 73, 359.

Firzpatrick, R. J. (1961a) Blood concentration of oxytocin in labor. 7. Endocr. 22, xix.

FitzPatrick, R. J. (1961b) The estimation of small amounts of oxytocin in blood. Oxytocin. Ed. R. CaldeyroBarcia and H. Heller. Pergamon Press, London.

Fitzpatrick, R. J. \& WALMSLEY, C. F. (1962) The concentration of oxytocin in bovine blood during parturition. F. Physiol., Lond. 163, 13P.

Folley, S. J. \& KnAggs, G. S. (1964) Observations on oxytocin release in ruminants. J. Reprod. Fert. 8, 265. 
Hawker, R. W. \& Robertson, P. A. (1957) Oxytocin in human female blood. Endocrinology, 60, 652.

HAYs, R. L. \& VANDEMARK, N. L. (1953) Effect of stimulation of the reproductive organs of the cow on the release of an oxytocin-like substance. Endocrinology, 52, 634.

KNAGGS, G. S. (1963) Blood oxytocin levels in the cow during milking and in the parturient goat. 7. Endocr. 26, xxiv.

Mendez-Bauer, C. J., Carballo, M. A., Cabot, H. M., Negreiros de Paiva, C. E. \& GonzalesPanizza, V. H. (1961) Studies on plasma oxytocinase. Oxytocin. Ed. R. Caldeyro-Barcia and H. Heller. Pergamon Press, London.

SAwYER, W. H. (1954) Inactivation of oxytocin by homogenates of uteri and other tissues from normal and pregnant rats. Proc. Soc. exp. Biol. Med. 87, 463.

SNedecor, G. W. (1946) Statistical methods, 4th edn. The Collegiate Press, Ames, Iowa.

Tuppy, H. (1961) Biochemical studies of axytocinase. Oxytocin. Ed. R. Caldeyro-Barcia and H. Heller. Pergamon Press, London.

van Dongen, C. G. \& Hays, R. L. (1964) A bio-assay for oxytocic activity in untreated blood plasma. 7. Anim. Sci. 23, 1229.

van Dongen, C. G. \& Hays, R. L. (1966) A sensitive in vitro assay for oxytocin. Endocrinology, $78,1$. 